\title{
Seed germination and seedling development of white oat affected by silicon and phosphorus fertilization
}

\author{
Mariana Zampar Toledo²; Rodrigo Arroyo Garcia²; Alexandre Merlin²; Dirceu Maximino \\ Fernandes ${ }^{1 *}$ \\ ${ }^{1}$ UNESP/FCA - Depto. de Recursos Naturais/Ciência do Solo, R. José Barbosa de Barros, 1780 - C.P. 237 - \\ 18603-970 - Botucatu, SP - Brasil. \\ ${ }^{2}$ UNESP/FCA - Programa de Pós-Graduação em Agronomia/Agricultura. \\ *Corresponding author <dmfernandes@fca.unesp.br $>$
}

\begin{abstract}
Silicon (Si) fertilizers have been increasingly used in agriculture due to several benefits as acidity correction in tropical soils and positive effects on the development of grasses. Nutrient availability and plant nutrition play an important role in seed production and may affect the physiological quality of white oat seeds. The present study had as objective to evaluate seed germination and seedling development of white oat (Avena sativa L.) affected by silicon and phosphorus fertilization. The experimental design was the completely randomized, analyzed as a factorial $2 \times 4$, with six replications. Treatments consisted of 20 and $200 \mathrm{mg} \mathrm{dm}^{-3}$ of $\mathrm{P}_{2} \mathrm{O}_{5}$, applied as triple superphosphate, combined with $0,150,300$ and $450 \mathrm{mg} \mathrm{dm}^{-3}$ of Si, as potassium silicate. The experiment was carried out in greenhouse, with seven plants per 15-L pot. Panicles were harvested and threshed manually and white oat seeds were stored in paper bags under normal environmental conditions. Seeds were evaluated by moisture content, seed weight, germination, electrical conductivity, seedling length and dry matter. White oat seeds with better quality are produced with $20 \mathrm{mg} \mathrm{dm}^{-3}$ of $\mathrm{P}_{2} \mathrm{O}_{5}$ under any Si doses. Higher seed germination and vigor is obtained with 300 and $450 \mathrm{mg} \mathrm{dm}^{-3}$ of $\mathrm{K}_{2} \mathrm{SiO}_{3}$, respectively. Silicon doses decreased root and total seedling length similarly up to the dose of $300 \mathrm{~kg} \mathrm{ha}^{-1}$ but $\mathrm{P}$ dose only influenced seedling development distinctively whenever applied with the higher silicon dose.
\end{abstract}

Key words: Avena sativa L., germination, vigor, plant nutrition

\section{Qualidade fisiológica de sementes de aveia-branca em função da adubação com silício e fósforo}

\begin{abstract}
RESUMO: Os fertilizantes silicatados tem sido cada vez mais usados na agricultura devido a inúmeros benefícios, tais como correção da acidez de solos tropicais e efeitos positivos no desenvolvimento de gramíneas. A disponibilidade de nutrientes e a nutrição de plantas desempenham papel importante na produção de sementes e podem influenciar a qualidade fisiológica de sementes de aveia-branca (Avena sativa L.). Avaliou-se a germinação de sementes e o desenvolvimento de plântulas de aveia-branca em função da adubação com silício e fósforo. $\mathrm{O}$ delineamento experimental foi inteiramente casualizado, em esquema fatorial $2 \times 4$, com seis repetições. Os tratamentos consistiram de 20 e $200 \mathrm{mg} \mathrm{dm}^{-3}$ de $\mathrm{P}_{2} \mathrm{O}_{5}$, aplicados na forma de superfosfato triplo, combinados com 0, 150, 300 e $450 \mathrm{mg} \mathrm{dm}^{-3}$ de Si na forma de silicato de potássio. O experimento foi realizado em casa de vegetação, conduzindo-se sete plantas por vaso, com capacidade para $15 \mathrm{~L}$ de terra. As panículas foram colhidas e debulhadas manualmente e, as sementes, armazenadas em sacos de papel em condições normais de ambiente. As sementes foram avaliadas quanto ao teor de água, massa de sementes, germinação, condutividade elétrica, comprimento e massa da matéria seca de plântulas. Sementes de aveia-branca com qualidade superior são produzidas com $20 \mathrm{mg} \mathrm{dm}^{-3}$ de $\mathrm{P}_{2} \mathrm{O}_{5}$, independente da dose de Si. Sementes com maior germinação e vigor são obtidas com 300 e $450 \mathrm{mg} \mathrm{dm}{ }^{-3} \mathrm{de} \mathrm{K}_{2} \mathrm{SiO}_{3}$, respectivamente. Os comprimentos da raiz e total das plântulas foram inferiores nas doses de Si até $300 \mathrm{~kg} \mathrm{ha}^{-1}$, porém a dose de fósforo somente afetou o desenvolvimento das plântulas de maneira distinta quando aplicada junto com a maior dose de silício.
\end{abstract}

Palavras-chave: Avena sativa L., germinação, vigor, nutrição de plantas

\section{Introduction}

White oat (Avena sativa L.) is widely cropped in rotation systems in no tillage system (Ceccon et al., 2004). Due to its great importance, studies to improve crop production have been developed, including some about seed technology (Nakagawa et al., 1994, 1996, 2000; Reis et al., 1992, 1993; Rossetto and Nakagawa, 1995). Poor quality seeds will lead to low population and the crop will be more susceptible to pathogen and insect attacks. Understanding either the influence of the seed used or the soil conditions in which the seed is sown is essential for crop establishment (Hegarty, 1976). Among the factors that affect seed vigor, plant nutrition plays an important role (Copeland and McDonald, 1995).

For better crop development, soil fertility has great importance, thus plant nutritional status may affect seed quality (Dornbos Jr., 1995). In Brazil, several authors 
have shown that black oat responds positively to phosphorus (P) fertilization (Rodrigues et al., 1985; Nakagawa and Rosolem, 2005), similarly to white oat (Kelling and Fixen, 1992). Silicon (Si) is not considered an essential element for plant growth, but some silicates have been increasingly used in agriculture, mainly due to several benefits to plant development, especially for grasses. Some of them are related to Si deposition on cell wall of many plant organs (Ma and Yamaji, 2006).

In rice, some authors have found $\mathrm{Si}$ affecting seed weight (Balastra et al., 1989). According to Carvalho and Nakagawa (2000), heavier seeds usually have better developed embryos and higher amount of reserves. Lee et al. (1985) also observed, in rice, that silicate application improved seed coat development, affecting physiological quality (Korndörfer at al., 2001). Being a precursor for the synthesis of lignin, Si may improve coat resistance, decreasing seed susceptibility to mechanical damage and metabolite leaching, as already reported by Alvarez et al. (1997) and Panobianco et al. (1999) in soybean. The present study had as objective to evaluate seed germination and seedling development of white oat affected by silicon and phosphorus fertilization.

\section{Material and Methods}

The experiment was carried out under greenhouse conditions in Botucatu, State of São Paulo, Brazil, from April to September of 2008. For seed production, a portion of soil was taken from a $0-20 \mathrm{~cm}$ layer of a Rhodic Ferralsol (FAO, 2006) with $630 \mathrm{~g} \mathrm{~kg}^{-1}, 40 \mathrm{~g} \mathrm{~kg}^{-1}$ and $330 \mathrm{~g}$ $\mathrm{kg}^{-1}$ of sand, silt and clay, respectively. Soil was dried under normal environmental conditions and passed through $2 \mathrm{~mm}$ sieves. Afterwards, samples were taken at random for soil chemical analysis (van Raij et al., 2001) that showed: $\mathrm{pH}\left(0.01 \mathrm{M} \mathrm{CaCl}_{2}\right): 4.1$; organic matter: $17 \mathrm{~g}$ $\mathrm{dm}^{-3} ; \mathrm{P}_{\text {resin }}: 3 \mathrm{mg} \mathrm{dm}{ }^{-3} ; \mathrm{H}+\mathrm{Al}: 69 \mathrm{mmol} \mathrm{dm}^{-3} ; \mathrm{K}: 0.3 \mathrm{mmol}$ $\mathrm{dm}^{-3}$; Ca: $2 \mathrm{mmol}_{\mathrm{c}} \mathrm{dm}^{-3}$; $\mathrm{Mg}: 1 \mathrm{mmol}_{\mathrm{c}} \mathrm{dm}^{-3}$; CEC: 72 mmol $\mathrm{dm}^{-3}$ and $4 \%$ of base saturation. Dolomitic lime (CaO: 28\%, MgO: 20\%; ECC: 95\%) was applied to raise base saturation up to $70 \%$ (van Raij et al., 1996). After liming, the soil remained for 30 days inside plastic bags with moisture content close to the field capacity.

The experimental design was the completely randomized, analyzed as a factorial $2 \times 4$, with six replications. Treatments consisted of 20 and $200 \mathrm{mg} \mathrm{dm}^{-3}$ of $\mathrm{P}_{2} \mathrm{O}_{5}$ combined with $0,150,300$ and $450 \mathrm{mg} \mathrm{dm}^{-3}$ of Si, applied at sowing. Regarding $\mathrm{P}$ fertilization, $20 \mathrm{mg} \mathrm{dm}^{-3}$ of $\mathrm{P}_{2} \mathrm{O}_{5}$ was applied because it was the minimum condition for white oat plants to develop properly until seed harvest. Triple superphosphate and potassium silicate $31 \%$ of $\mathrm{SiO}_{2}$ and $13 \%$ of $\mathrm{K}_{2} \mathrm{O}$ ) were used as $\mathrm{P}$ and $\mathrm{Si}$ sources, respectively. Fertilizers were separated for each $15-\mathrm{L}$ pot and mixed with soil at sowing time. The amount of $\mathrm{K}$ from the silicate fertilizer was corrected to make up for the difference among the treatments, using additional potassium chloride. Nitrogen, as urea, was applied in the dose of $50 \mathrm{mg} \mathrm{dm}^{-3}$ at sowing and 25 days after seedling emergence.
Before the beginning of the experiment, white oat seeds were pre germinated in the laboratory for two days to provide uniform seedling development. Seeds were distributed on paper towels moistened with water equivalent to twice the weight of the dry paper. Then, rolls were made and left for germination at $20^{\circ} \mathrm{C}$ (Brazil, 1992). After this period, 12 pre germinated seeds were sown in each pot. Thinning was carried out ten days after sowing so that just seven seedlings remained in each experimental unit. During the experiment, soil moisture was maintained close to the field capacity. At seed physiological maturity stage, panicles were harvested and threshed manually. Two greenhouse replications were joined in one, and the six replications formed only three, to obtain enough seeds of each treatment for the evaluations of physiological quality.

Seeds were stored in paper bags under environmental conditions for 20 days. Mean temperature and relative humidity in the laboratory were $26.2^{\circ} \mathrm{C}$ and $41.7 \%$, respectively. Seeds were evaluated by the following tests:

Water content: two replications of 20 seeds per treatment were evaluated using an oven at $105 \pm 3^{\circ} \mathrm{C}$ for $24 \mathrm{~h}$ (wet basis); results were expressed as a percentage (Brazil, 1992).

Germination: four replications of 50 seeds were distributed on paper towels moistened with water equivalent to twice the weight of the dry paper. Rolls were made and placed into plastic bags and left for germination at $20^{\circ} \mathrm{C}$. Evaluation took place ten days after sowing (Brazil, 1992) and results were expressed as the mean percentage of normal seedlings.

First count of germination: it was performed along with the germination test; the percentage of normal seedlings was recorded on the fifth day after sowing.

Electrical conductivity: 50 seeds of each replication were weighed and soaked into $200 \mathrm{~mL}$ plastic cups containing $100 \mathrm{~mL}$ of deionized water, for $24 \mathrm{~h}$ at $25^{\circ} \mathrm{C}$ (Vieira and Krzyzanowski, 1999); afterwards, the electrical conductivity of the solution was determined through reading in a conductivimeter.

Seedling length: four replications of ten seeds per treatment were sown on a line drawn on paper towels moistened with water equivalent to two times the weight of the dry paper. Rolls were made and placed into plastic bags and left for germination in an upright position at $20^{\circ} \mathrm{C}$ for 5 days (Nakagawa, 1999). Shoot, primary root and total length of white oat seedlings were measured in $\mathrm{cm}$.

Seedling dry matter: normal seedlings of the seedling length test were placed into paper bags and dried using an oven at $80^{\circ} \mathrm{C}$ for $24 \mathrm{~h}$. Results were obtained dividing each weight by the number of normal seedlings (Nakagawa, 1999). Then, the means were obtained for each treatment, in $\mathrm{mg}$. 
Seed weight: was obtained by weighing four replications of 100 seeds from each treatment. Results were expressed in grams (Brazil, 1992).

Variance tests were applied for statistical analysis. Whenever no significant interaction was found, means for $\mathrm{P}$ condition were compared by the Tukey test $(p \leq 0.05)$ and $S i$ doses by regression analysis. Whenever significant interaction was observed, the Tukey test $(p \leq 0.05)$ was applied and interaction slicing was used to compare $\mathrm{P}$ treatments in each Si dosage. Also, regression analysis evaluated Si fertilization for each $\mathrm{P}$ treatment, choosing the significant equations with the higher coefficient of determination.

\section{Results and Discussion}

Water content of white oat seeds was uniform for all treatments (Table 1). Marcos Filho (2005) reported that small moisture variations are important to obtaining consistent results of seed physiological quality. There were no interactive effects of $\mathrm{P}$ and $\mathrm{Si}$ on shoot length, seedling dry matter and seed weight (Table 2). However, either shoot length and seed weight were affected by Si doses. Seed weight was linearly decreased with the application of higher Si doses. Potassium sili-

Table 1 - Water content (\%) of white oat seeds as affected by Si doses and two levels of $P$.

\begin{tabular}{lccrc}
\hline \multirow{2}{*}{$\mathrm{P}$ dose } & \multicolumn{4}{c}{ Si doses } \\
\cline { 2 - 5 } & 0 & 150 & 300 & 450 \\
\hline $\mathrm{mg} \mathrm{dm} \mathrm{dm}^{-3}$ of $\mathrm{P}_{2} \mathrm{O}_{5}$ & - & \multicolumn{4}{c}{$\mathrm{mg} \mathrm{dm}^{-3}$} & \\
\hline 20 & 9.0 & 8.9 & 8.9 & 8.6 \\
200 & 9.4 & 9.1 & 8.9 & 9.0 \\
\hline
\end{tabular}

cate doses up to $150 \mathrm{mg} \mathrm{dm}^{-3}$ decreased shoot length with a subsequent increase with higher rates. The other physiological evaluations showed effects of the interaction of P and Si. Carvalho et al. (2000) found that silicate anions $\left(\mathrm{H}_{3} \mathrm{SiO}_{4}\right)$ may become available due to silicate application. These may compete with the phosphate anion for the same sorption sites. Frequently, the identification of the effects of specific elements on seed quality is harmed by the interaction among them (Marcos Filho, 2005), as may be observed for Si and P.

Except for seed weight, the fertilization with the higher $P$ concentration affected the results (Table 2). In this experiment, higher $\mathrm{P}$ availability increased seedling dry matter and decreased electrical conductivity, both indicating high quality seeds (Woodstock, 1973). Sá (1994) described the importance of plant fertilization on seed quality and pointed out several studies where $P$ had favorable effects on maturation and vigor of cereal seeds. Higher $\mathrm{P}$ levels in soil decreased seed quality, possibly due to higher plant tillering and production of lighter seeds. Corrêa and Haag (1993 a, b) observed that P plays an important role in tillering of grasses in general. Coimbra and Nakagawa (2006) showed different quality levels of millet seeds produced by plants with a variable number of tillers. The same authors observed that seeds from the main stem were heavier than the ones from the tillers, indicating that higher tillering results in higher number of seeds, but with lower weight and physiological quality, probably because they are still immature.

For the lower level of $\mathrm{P}$ in soil, Si doses did not influence seed quality evaluated by germination, first count and electrical conductivity tests (Figure 1). Nevertheless, even with no response to Si doses, means were higher than those obtained for seeds produced under higher $\mathrm{P}$ conditions, for all Si doses. Nakagawa et al. (2001) also

Table 2 - Germination percentage (G), germination first count (FC), electrical conductivity (EC), root length (RL), shoot length (SL), total seedling length (TL), seedling dry matter (SDM) and weight (SW) of white oat seeds as affected by Si doses and two levels of $\mathrm{P}$.

\begin{tabular}{|c|c|c|c|c|c|c|c|c|}
\hline Treatment & G & $\mathrm{FC}$ & EC & RL & SL & $\mathrm{TL}$ & SDM & $\mathrm{W}$ \\
\hline & \multicolumn{2}{|c|}{ - } & $\mu \mathrm{S} \mathrm{cm}^{-1} \mathrm{~g}^{-1}$ & 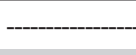 & $\mathrm{cm}$ & - & $\mathrm{mg}$ & $\mathrm{g}$ \\
\hline \multicolumn{9}{|l|}{ Si dose $\left(\mathrm{mg} \mathrm{dm}^{-3}\right)$} \\
\hline 0 & 78 & 69 & 227.62 & 6.67 & 4.16 & 10.83 & 27.15 & 3.47 \\
\hline 150 & 86 & 74 & 207.61 & 4.43 & 3.52 & 7.95 & 32.59 & 3.24 \\
\hline 300 & 84 & 75 & 202.11 & 4.62 & 3.64 & 8.26 & 29.34 & 3.22 \\
\hline 450 & 83 & 75 & 180.82 & 6.11 & 3.91 & 10.02 & 30.43 & 3.21 \\
\hline Regression & - & - & - & - & $\mathrm{Q}^{(1)}$ & - & ns & $\mathrm{L}^{(2)}$ \\
\hline \multicolumn{9}{|l|}{$\mathrm{P}$ dose $\left(\mathrm{mg} \mathrm{dm}^{-3}\right)$} \\
\hline 20 & $90 \mathrm{a}^{(3)}$ & $79 \mathrm{a}$ & $225.61 \mathrm{~b}$ & $6.12 \mathrm{a}$ & $4.02 \mathrm{a}$ & $10.14 \mathrm{a}$ & $26.69 \mathrm{~b}$ & 3.13 \\
\hline 200 & $75 \mathrm{~b}$ & $68 \mathrm{~b}$ & $183.47 \mathrm{a}$ & $4.80 \mathrm{~b}$ & $3.59 \mathrm{~b}$ & $8.39 \mathrm{~b}$ & $33.06 \mathrm{a}$ & 3.19 \\
\hline LSD & 6.31 & 8.15 & 19.12 & 0.91 & 0.55 & 1.25 & 6.53 & 0.29 \\
\hline Interaction $\mathrm{P} \times \mathrm{Si}$ & $6.53 \%$ & $6.26 * *$ & $11.25^{* * *}$ & $4.32 \% *$ & $2.41 \mathrm{~ns}$ & $3.38^{*}$ & $0.19 \mathrm{~ns}$ & $1.65 \mathrm{~ns}$ \\
\hline C.V. (\%) & 9.41 & 13.73 & 11.52 & 20.47 & 17.95 & 16.61 & 26.95 & 11.16 \\
\hline
\end{tabular}

${ }^{1} y=1 E-05 x^{2}-0.005 x+4.1295 ; R^{2}=0.92 * * .{ }^{2} y=-0.0005 x+3.403 ; R^{2}=0.69 * .{ }^{3}$ Means followed by the same small letter in the column do not differ (Tukey test, $p \leq 0.05$ ). * and $* *$ significant at 5 and $1 \%$ of probability, respectively; ns: non significant 

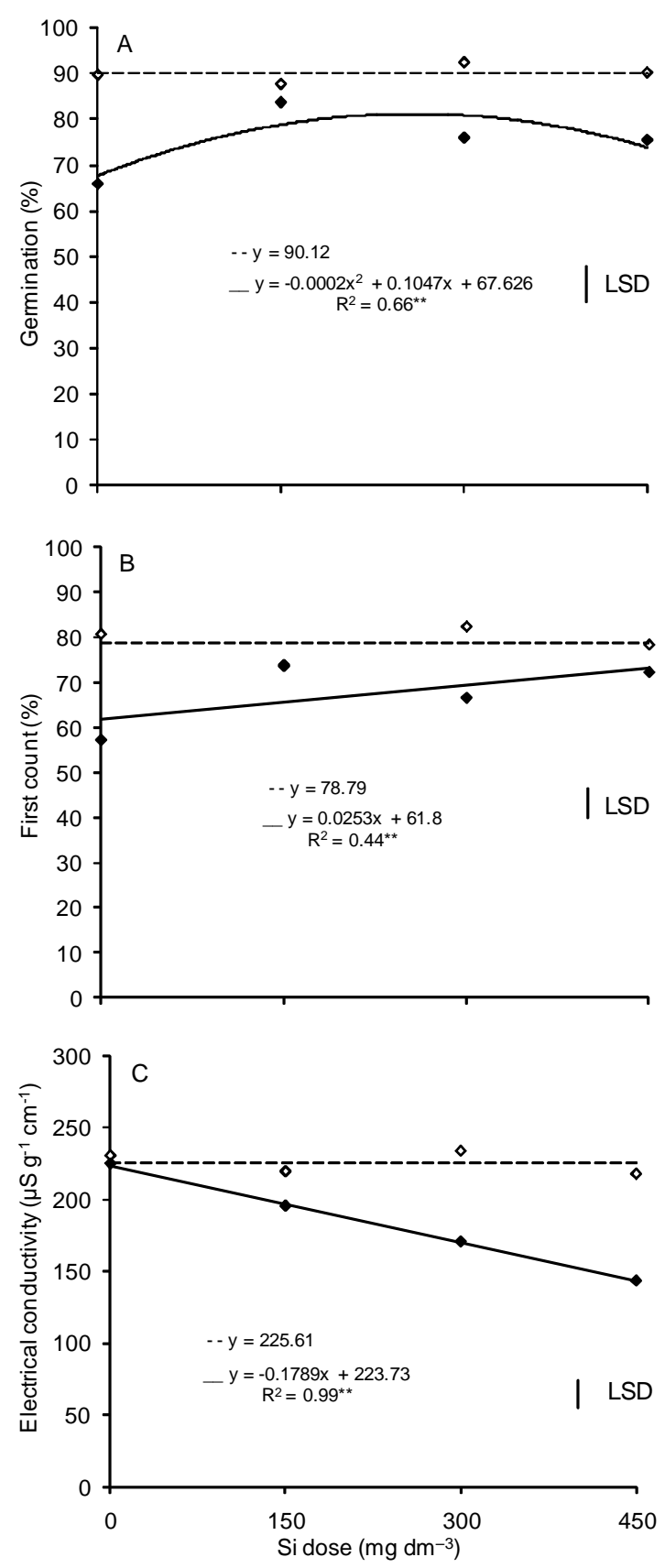

Figure 1 - Germination percentage (A), germination first count (B) and electrical conductivity (C) of white oat seeds as affected by Si doses and $\mathrm{O}(\diamond)$ and $200(\diamond) \mathrm{mg} \mathrm{dm}^{-3}$ of $\mathrm{P}_{2} \mathrm{O}_{5}$. LSD: least significant difference (Tukey test, $p \leq 0.05)$.

reported the effects of $\mathrm{P}$ doses on seed quality, evaluated by the germination first count test, and recommended the doses of 0 and $40 \mathrm{~kg} \mathrm{ha}^{-1}$ of $\mathrm{P}_{2} \mathrm{O}_{5}$ to produce black oat seeds with higher quality. The authors mentioned that although these $\mathrm{P}$ rates are considered low, they are sufficient for the normal development of black oat plants.

When $200 \mathrm{mg} \mathrm{dm}^{-3}$ of $\mathrm{P}_{2} \mathrm{O}_{5}$ was applied, germination data was influenced by Si doses (Figure 1). Si fertilization increased seed germination up to the dose of 300 $\mathrm{kg} \mathrm{ha}^{-1}$. Considering the first count test, the number of normal seedlings linearly increased with higher Si doses. Matichenkov et al. (2005) observed that wheat germination was increased with Si doses. This may be an indirect effect of seed weight. Carvalho and Nakagawa (2000) mentioned that heavier seeds usually have better developed embryos and higher amount of reserves. Balastra et al. (1989), Deren et al. (1994) and Mauad et al. (2003) had already observed that silicon increased weight of rice seeds. The likely explanation for the increase in seed weight would be the greater deposition of this element on the paleae and lemmas, as reported by Balastra et al. (1989). This greater deposition is attributed to intense panicle transpiration during the seed filling stage, since the process of transportation and deposition of silicon in plant tissues depends upon the transpiration rates that occur in different plant organs (Yoshida et al., 1962). In this study, seed germination was increased because there was an interactive effect of $\mathrm{Si}$ and P. Significant effects of silicate doses were observed whenever $200 \mathrm{mg} \mathrm{dm}^{-3}$ of $\mathrm{P}$ was applied. However, seed weight was only affected by silicate application.

Results of electrical conductivity were affected by Si doses for the higher level of $\mathrm{P}$ applied at sowing (Figure 1). Silicon is not considered within the group of essential or functional nutrients for plant growth, but its absorption has several benefits (Mauad et al., 2003). Mengel and Kirkby (2001) reported that silicic acid reacts with phenols, like the caffeic acid, which is the precursor for the synthesis of lignin. This relation of silicon and lignin synthesis is an important approach to study Si biochemical functions. Korndörfer et al. (2001) verified that Si influenced coat development of rice seeds, indirectly increasing seed physiological quality.

Silicon fertilization affected seed quality whenever $P$ was applied (Figure 1). Many studies about fertilization of oat plants have been carried out (Brown et al., 1961; Forsberg and Reeves, 1995; Gaspar et al., 1994; Kelling and Fixen, 1992; Peterson et al., 1974; Portch et al., 1968); however, none of them pointed out the interaction among nutrients. Si fertilization increases $\mathrm{P}$ solubility and decreases fixation (Plucknett, 1972). Positive silicate effects are usually associated with increases of silicon availability and with higher availability of phosphorus (Smyth and Sanchez, 1980). The anions formed after silicate application compete with phosphates for the same sorption sites and thus increase $\mathrm{P}$ availability (Pereira et al., 2004).

Quadratic equations were adjusted to the results of root length and total seedling length. Both behaviors were similar in both P levels (Figure 2). Unlike the results of seed germination, higher Si doses decreased root length and total length of white oat seedlings up to the dose of $300 \mathrm{~kg} \mathrm{ha}^{-1}$. Although P and Si had no interactive effects on shoot length, means were also adjusted by a quadratic equation and the effects of $\mathrm{Si}$ were similar (Table 2).

Positive effects of Si fertilization on seed quality have been reported by some authors. However, Si seems to 

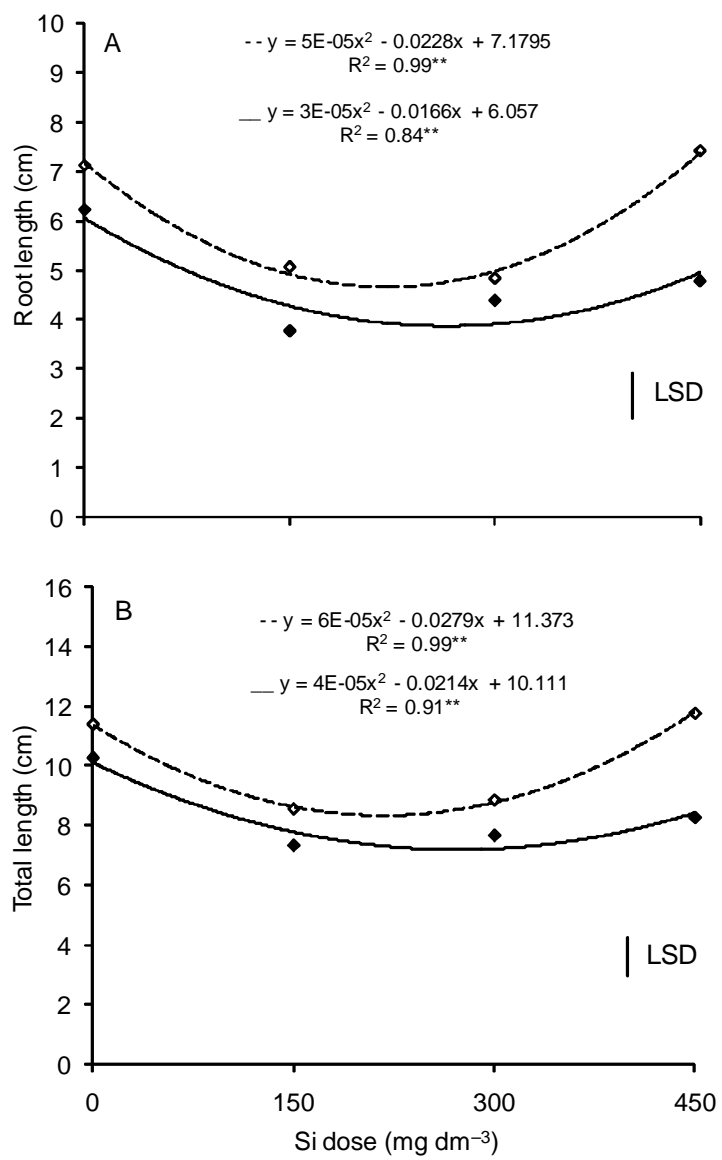

Figure 2 - Root length (A) and total seedling length (B) of white oat seedlings as affected by $\mathrm{Si}$ doses and $\mathrm{O}$ $(\diamond)$ and $200(\diamond) \mathrm{mg} \mathrm{dm}{ }^{-3}$ of $\mathrm{P}_{2} \mathrm{O}_{5}$. LSD: least significant difference (Tukey test, $p \leq 0.05$ ).

influence other characteristics rather than germination and vigor, which are indirectly affected, such as disease suppression (Datnoff et al., 1997), spikelet fertility (Ma et al., 1989) and seed weight (Balastra et al., 1989; Deren et al., 1994). Whenever plants are cropped under favorable conditions, especially free of diseases, both high quality seeds and yields may be achieved. Plants appropriately fertilized and nutritionally well balanced may produce seeds with better physiological quality (Sá, 1994).

Silicon fertilization has many benefits and can be done using several sources, such as wollastonite, slag and other silicates. Although potassium silicate is not economically convenient to be used as fertilizer in Brazil, other sources, such as slag and $\mathrm{Ca}+\mathrm{Mg}$ silicate, can be achieved at a low price because they are residues of the steel industry and many studies have already been carried out about their effects on crop nutrition (Pereira et al., 2004; Carvalho-Pupatto et al., 2004).

\section{Conclusions}

White oat seeds with higher physiological quality are produced under the dose of $20 \mathrm{mg} \mathrm{dm}^{-3}$ of $\mathrm{P}_{2} \mathrm{O}_{5}$ for any Si conditions. Higher Si doses linearly increased germination first count and decreased electrical conductivity, which indicate high quality seeds produced under $450 \mathrm{mg} \mathrm{dm}^{-3}$ of $\mathrm{K}_{2} \mathrm{SiO}_{3}$, differently from the germination percentage that was increased only up to the application of $300 \mathrm{~kg} \mathrm{ha}^{-1}$ of potassium silicate. Silicon doses decrease root and total seedling length similarly up to the dose of $300 \mathrm{~kg} \mathrm{ha}^{-1}$; the amount of $\mathrm{P}$ applied only influenced seedling development along with the higher Si dose.

\section{References}

Alvarez, P.J.C.; Krzyzanowski, F.C.; Mandarino, J.M.G.; França Neto, J.B. 1997. Relationship between soybean seed coat lignin content and resistance to mechanical damage. Seed Science and Technology 25: 209-214.

Balastra, M.L.F.; Perez, C.M.; Juliano, B.O.; Villreal, P. 1989. Effects of silica level on some proprieties of Oryza sativa straw and hult. Canadian Journal of Botany 67: 2356-2363.

Brazil. Ministério de Reforma Agrária. 1992. Brazilian Rules for Seed Analysis. SNDA/DNDV/CLAV, Brasília, DF, Brazil. (in Portuguese).

Brown, A.R.; Morris, H.D.; Morey, D.D. 1961. Response of seven oat varieties to different levels of fertilization. Agronomy Journal 53: 366-369.

Carvalho, N.M.; Nakagawa, J. 2000. Seeds: Science, Technology and Production. 4ed. FUNEP, Jaboticabal, SP, Brazil. (in Portuguese).

Carvalho, R.; Furtine Neto, A.E.; Nilton, C.; Fernandes, L.A. 2000. Phosphorus desorption by silicon in soils cultivated with eucalyptus. Revista Brasileira de Ciência do Solo 24: 69-74. (in Portuguese, with abstract in English).

Carvalho-Pupatto, J.G.; Büll, L.T.; Crusciol, C.A.C. 2004. Soil chemical attributes, root growth and rice yield according to slag application. Pesquisa Agropecuária Brasileira 39: 1213-1218. (in Portuguese, with abstract in English).

Ceccon, G.; Grassi Filho, H.; Bicudo, S.J. 2004. White oat (Avena sativa L.) grains yield using different plant densities and nitrogen levels. Ciência Rural 34: 1723-1729. (in Portuguese, with abstract in English).

Coimbra, R.A.; Nakagawa, J. 2006. Sowing time, production and physiological quality of pearl millet seeds. Revista Brasileira de Sementes 28: 53-59. (in Portuguese, with abstract in English).

Copeland, L.O.; McDonald, M.B. 1995. Principles of Seed Science and Technology. 2ed. Burgess, Minneapolis, MN, USA.

Corrêa, L.A.; Haag, H.P. 1993a. Critical levels of phosphorus for the establishment of pasture grasses on a Red Yellow Latosol. I. Greenhouse test. Scientia Agricola 50: 99-110. (in Portuguese, with abstract in English).

Corrêa, L.A.; Haag, H.P. 1993b. Critical levels of phosphorus for the establishment of pasture grass on a Red Yellow Latosol. II. Field test. Scientia Agricola 50: 109-116. (in Portuguese, with abstract in English).

Datnoff, L.E.; Deren, C.W.; Snyder, G.H. 1997. Silicon fertilization for disease management of rice in Florida. Crop Protection 16: 525-531.

Deren, C.W.; Datnoff, L.E.; Snyder, G.H.; Martin, F.G. 1994. Silicon concentration, disease response, and yield components of rice genotypes grown on flooded organic histosols. Crop Science 34: 733-737.

Dornbos Jr., D.L. 1995. Production environment and seed quality. p. 119-152. In: Basra, A.S., ed. Seed quality: basic mechanisms and agricultural implications. Food Products Press, New York, NY, USA.

Food and Agriculture Organization of the United Nations [FAO]. 2006. World Soil Resources Report. FAO, Rome, Italy. (World Reference Base for Soil Resources, 103). 
Forsberg, R.A.; Reeves, D.L. 1995. Agronomy of oats. p. 223-251. In: Welch, R.W., ed. The oat crop: production and utilization. Chapman and Hall, London, UK.

Gaspar, P.E.; Reeves, D.L.; Schumacher, T.E.; Fixen, P.E. 1994. Oat cultivar response to potassium chloride on soils testing high in potassium. Agronomy Journal 86: 255-258.

Hegarty, T.W. 1976. Field establishment of some vegetable crops: response to a range of soil conditions. Journal of the American Society for Horticultural Science 51: 133-146.

Kelling, K.A.; Fixen, P.E. 1992. Soil and nutrient requirements for oat production. p. 165-190. In: Marshall, H.G.; Sorrells, M.E., eds. Oat science and technology. American Society of Agronomy/Crop Science Society of America, Madison, WI, USA.

Korndörfer, G.H.; Snyder, G.H.; Ulloa, M.; Powell, G.; Datnoff, L.E. 2001. Calibration of soil and plant silicon analysis for rice production. Journal of Plant Nutrition 24: 1071-1084.

Lee, K.S.; Ahn, S.B.; Rhee, G.S.; Yeon, B.Y.; Park, J.K. 1985. Studies of silica application to nursery beds on rice seedling growth. Research Report of the Rural Development Administration, Plant Environment, Mycology, Farm Product Utilization of the Korea Republic 27: 23-27.

Ma, J.F.; Nishimra, K.; Takahashi, E. 1989. Effect of silicon on the growth of rice plant at different growth stages. Soil Science and Plant Nutrition 35: 347-356.

Ma, J.F.; Yamaji, N. 2006. Silicon uptake and accumulation in higher plants. Trends in Plant Science 11: 342-397.

Marcos Filho, J. 2005. Seed physiology of cultivated plants. FEALQ, Piracicaba, SP, Brazil. (in Portuguese).

Matichenkov, V.V.; Kosobrukhov, A.A.; Shabnova, N.I.; Bocharnikova, E.A. 2005. Plant response to silicon fertilizers under salt stress. Agrokhimiya 10: 59-63.

Mauad, M.; Crusciol, C.A.C.; Grassi Filho, H.; Correa, J.C. 2003. Nitrogen and silicon fertilization of upland rice. Scientia Agricola 60: 761-765.

Mengel, K.; Kirkby, E.A. 2001. Principles of Plant Nutrition. 5ed. Kluwer Academic, Dordrecht, Netherlands.

Nakagawa, J. 1999. Vigor tests based on seedling performance. cap. 1, p. 1-24. In: Krzyzanowski, F.C.; Vieira, R.D.; França Neto, J.B., eds. Seed vigor: definitions and tests. ABRATES, Londrina, PR, Brazil. (in Portuguese).

Nakagawa, J.; Cavariani, C.; Guiscem, J.M. 2001. Effects of phosphated and potassic fertilization on the electrical condutivity test of black oat seeds. Revista Brasileira de Sementes 23: 302-308. (in Portuguese, with abstract in English).

Nakagawa, J.; Cavariani, C.; Machado, J.R. 1994. Seed maturation of Avena strigosa (Schreb.). I. Field maturity. Pesquisa Agropecuária Brasileira 29: 315-326. (in Portuguese, with abstract in English).

Nakagawa, J.; Cavariani, C.; Machado, J.R. 1996. Effect of nitrogen fertilization (at panicle emergence) on yield and seed quality of Avena strigosa Schreber. Revista Brasileira de Sementes 18: 160166. (in Portuguese, with abstract in English).

Nakagawa, J.; Cavariani, C.; Machado, J.R. 2000. Nitrogen fertilization at tillering of black oat in two soil fertility conditions. Pesquisa Agropecuária Brasileira 35: 1071-1080. (in Portuguese, with abstract in English).

Nakagawa, J.; Rosolem, C.A. 2005. Nutrient concentration in leaves and grains of black oat affected by phosphorus and potassium fertilization. Bragantia 64: 441-445. (in Portuguese, with abstract in English).
Panobianco, M.; Vieira, R.D.; Krzyzanowski, F.C.; França Neto, J.B. 1999. Electrical conductivity of soybean seed and correlation with seed coat lignin content. Seed Science and Technology 27: 945-949.

Pereira, H.S.; Korndörfer, G.H.; Vidal, A.A.; Camargo, M.S. 2004. Silicon sources for the rice plants. Scientia Agricola 61: 522-528.

Peterson, D.M.; Schrader, L.E.; Youngs, V.L. 1974. Elemental composition of developing oat plants. Crop Science 14: 735739.

Plucknett, D.L. 1972. The use of soluble silicates in Hawaii agriculture. University of Queensland Papers 1: 203-223.

Portch, S.; Mackenzie, A.F.; Steppler, H.A. 1968. Effects of fertilizers, soil drainage class and year upon protein yield and content of oats. Agronomy Journal 60: 672-674.

Reis, R.A.; Rodrigues, L.R.A.; Coan, O.; Resende, K.T. 1992. Effects of different harvest periods on bristle oat forage and seed production. Pesquisa Agropecuária Brasileira 27: 111-117. (in Portuguese, with abstract in English).

Reis, R.A.; Rodrigues, L.R.A.; Vieira, R.D.; Guimarães, P.H.P. 1993. Production and quality of seeds in forage oats. Pesquisa Agropecuária Brasileira 28: 1425-1430. (in Portuguese, with abstract in English).

Rodrigues, A.N.A.; Volkweiss, S.J.; Anghinoni, I. 1985. Immediate and residual effects of triple superphosphate on dry matter yield and phosphorus uptake by forage oats in a Rhodic Paleudult soil. Revista Brasileira de Ciência do Solo 9: 219-224. (in Portuguese, with abstract in English).

Rossetto, C.A.V.; Nakagawa, J. 1995. Avena strigosa (Schreb) seed yield and quality as affected by sowing time. Científica 23: 171184. (in Portuguese, with abstract in English).

Sá, M.E. 1994. Importance of fertilization on seed quality. p. 65-98. In: Sá, M.E.; Buzeti, S. Importance of fertilization on quality of agricultural products. Icone, São Paulo, SP, Brazil. (in Portuguese).

Smyth, T.J.; Sanchez, P.A. 1980. Effects of lime, silicate, and phosphorus applications to an Oxisol on phosphorus sorption and ion retention. Soil Science Society of America Journal 44: 500-505.

Van Raij, B. van; Andrade, J.C.; Cantarella, H.; Quaggio, J.A. 2001. Chemical analysis for evaluation of the fertility of tropical soils. Instituto Agronômico, Campinas, SP, Brazil. (in Portuguese).

Van Raij, B. van.; Cantarella, H.; Quaggio, J.A; Furlani, A.M.C. 1996. Fertilization and liming recommendation for the State of São Paulo. 2ed. Instituto Agronômico/Fundação IAC, Campinas, SP, Brazil. (in Portuguese).

Vieira, R.D.; Krzyzanowski, F.C. 1999. Electrical conductivity test. cap. 4, p. 1-26. In: Krzyzanowski, F.C.; Vieira, R.D.; França Neto, J.B., eds. Seed vigor: definitions and tests. ABRATES, Londrina, PR, Brazil. (in Portuguese).

Woodstock, L.W. 1973. Physiological and biochemical tests for seed vigor. Seed Science and Technology 1: 127-157.

Yoshida, S.; Ohnishi, Y.; Kitagishi, K. 1962. Chemical forms, mobility and deposition of silicon in rice plant. Soil Science and Plant Nutrition 8: 15-21.

Received October 02, 2009

Accepted May 14, 2010 